\title{
Embryonic Stem Cells Overexpressing the Recognition Molecules L1 and Tenascin-R Enhance Regeneration in Mouse Models of Acute and Chronic Neurological Disorders
}

\author{
Gunnar Hargus ${ }^{1,3}$ and Christian Bernreuther ${ }^{1,2}$ \\ ${ }^{1}$ Center for Molecular Neurobiology Hamburg, University Medical Center \\ Hamburg-Eppendorf, University of Hamburg, Martinistr. 52, 20246 Hamburg, \\ ${ }^{2}$ Institute of Neuropathology, University Medical Center Hamburg-Eppendorf, \\ University of Hamburg, Martinistrasse 52, 20246 Hamburg, Germany \\ 3present address: Udall Parkinson's Disease Research Center of Excellence and \\ Center for Neuroregeneration Research, McLean Hospital / Harvard Medical School, \\ 115 Mill Street, Belmont, Massachusetts 02478, \\ 1,2Germany \\ 3USA
}

\section{Introduction}

Important issues in transplantation of stem cells into the central nervous system that need to be solved to achieve restoration of function are adequate differentiation, survival, migration, and integration of transplanted cells. Furthermore, a major obstacle to transplantation of embryonic stem (ES) cells into the human brain is the formation of teratomas. In this chapter, we provide an overview on how cell adhesion molecules and extracellular matrix molecules can be applied to successfully modify ES cells for cell therapy approaches in animal models of neurological diseases, as both groups of recognition molecules provide important support to cells, participate in the control of cell development, and mediate cell survival both in vitro and in vivo. As an example from our own work, we describe how mouse ES cells that had been genetically modified to overexpress the neural cell adhesion molecule L1 or the extracellular matrix protein tenascin-R (TNR) promote several aspects of ES cell-mediated regeneration in animal models of neurological diseases. As a surface molecule on postmitotic neurons, L1 is expressed in the developing and adult central nervous system and has been shown to promote neuronal survival, neurite outgrowth, synapse formation, and cell migration. The extracellular matrix molecule TNR, on the other hand, is secreted by both subsets of neurons and myelinating oligodendrocytes in the postnatal brain, is a constituent of perineuronal nets, which promote cellular integrity and synaptic excitability of neurons, and can act as an attracting guidance molecule for migrating endogenous newborn neurons when ectopically expressed in vivo.

Both L1 and TNR promote neuronal differentiation of ES cells in vitro and increase survival of ES cell-derived neurons after transplantation in the adult rodent brain. L1-overexpressing 
ES cell-derived cells migrate over a longer distance after transplantation into the host brain and spinal cord in comparison to non-transfected control cells and mediate functional improvement in animal models of Parkinson's and Huntington's disease. In contrast, TNR does not support the migration of engrafted ES cell-derived cells, but attracts host-derived migrating neuroblasts from the rostral migratory stream in an animal model of Huntington's and promotes the recruitment of host-derived newborn neurons within the grafted area, thereby positively influencing the response of the host to engrafted ES cellderived cells.

Furthermore, we discuss different aspects of ES cell-mediated regeneration. We describe how genetic modifications have been applied to improve the ability of ES cells to differentiate into specific cellular subtypes in vitro. We review how fluorescent activated cell sorting for cell adhesion molecules has been applied on differentiating ES cells to prevent teratoma formation by cell purification, a necessary safety requirement in any potential clinical application of ES cells. These strategies are first steps in the validation of such procedures for therapy in humans. In summary, we provide an overview on how ES cells can be successfully modified for cell therapy approaches in animal models of neurological diseases highlighting the importance of neural cell adhesion molecules and extracellular matrix molecules.

\subsection{Characteristics and importance of embryonic stem cells}

About three decades ago, the first ES cell lines were established from mouse blastocysts and the isolation of human ES cells has been accomplished thereafter (Evans and Kaufman, 1981; Martin, 1981; Thomson et al., 1998). Under optimal conditions, ES cells have the ability to divide indefinitely and, as pluripotent stem cells, can differentiate into cells of the three germ layers mesoderm, endoderm and ectoderm. Therefore, ES cells have been widely used to study developmental processes in vitro and have been applied to generate gene knockout animals to study gene function in vivo. Furthermore, ES cells provide a useful tool for biomedical research and regenerative medicine, as ES cell-derived cells of interest (e.g. cardiomyocytes or neurons) can be used in toxicity assays or drug screens and, importantly, comprise a source for cell therapy in animal models of diseases to rescue or replace imperilled host-derived cells.

\subsection{Neuroectodermal differentiation of ES cells}

Since ES cells differentiate spontaneously into various cell types in vitro, while only certain ES cell-derived cell types are needed for cell-replacement therapy (e.g. neuroectodermal cells for the treatment of neurodegenerative diseases), several protocols have been established to direct the differentiation of ES cells into cells of a specific lineage. Neuroectodermal differentiation of ES cells can be induced by culturing ES cells at low density without the support of inactivated embryonic mouse fibroblasts (Tropepe et al., 2001). In this protocol ES cells follow a default pathway of neural differentiation. Other protocols apply a co-culture system to differentiating ES cells including MS5 feeder cells that express the signalling molecule Wnt-1 (Perrier et al., 2004) or PA6 feeder cells, which provide a stromal cell-derived inducing activity (SDIA) to differentiating ES cells (Kawasaki et al., 2002). Furthermore, the application of recombinant proteins to the culture medium has been shown to significantly promote neuroectodermal or even neural subtype specification of differentiating ES cells. Examples include noggin, an antagonist of the transforming growth factor $\beta$ family, which enhances neuroectodermal differentiation of ES cells (Pera et 
al., 2004; Itsykson et al., 2005; Sonntag et al., 2007), fibroblast factor 4 (FGF-4) to promote serotoninergic neuronal differentiation (Barberi et al., 2003), a combination of retinoic acid (RA) and sonic hedgehog (Shh) to improve cholinergic motor neuron differentiation (Wichterle et al., 2002) or a combination of Shh and FGF-8, which has been shown to direct differentiation of ES cells from various species into dopaminergic neurons (Cooper et al. 2010; Lee et al., 2000; Perrier et al., 2004; Sanchez-Pernaute et al., 2008). Finally, a lineage selection protocol has been established to generate a high number of FGF-2-responsive nestin-positive neural precursor cells from ES cells via so-called embryoid bodies by applying culture conditions, that favor the survival and proliferation of neural precursor cells but not of mesodermal and endodermal cell types (Okabe et al., 1996). Embryoid bodies represent aggregates of differentiating ES cells that consist of a core of ectoderm, mesoderm and endoderm surrounded by visceral and parietal endodermal cells (Maye et al., 2000) and have been applied as model system to study early cell differentiation in vitro (Rohwedel et al., 1994; Wobus et al., 1997; Guan et al., 1999; Hegert et al., 2002; Hargus et al., 2008b). The lineage selection protocol comprises 5 different stages and generates a high number of postmitotic neurons at the end of differentiation (Fig. 1). While this protocol has been optimized to enhance overall dopaminergic neuronal differentiation by the application of Shh and FGF-8 during stage 4 (Lee et al., 2000), we have slightly modified this protocol to promote GABAergic differentiation of ES cells in vitro (Bernreuther et al., 2006).

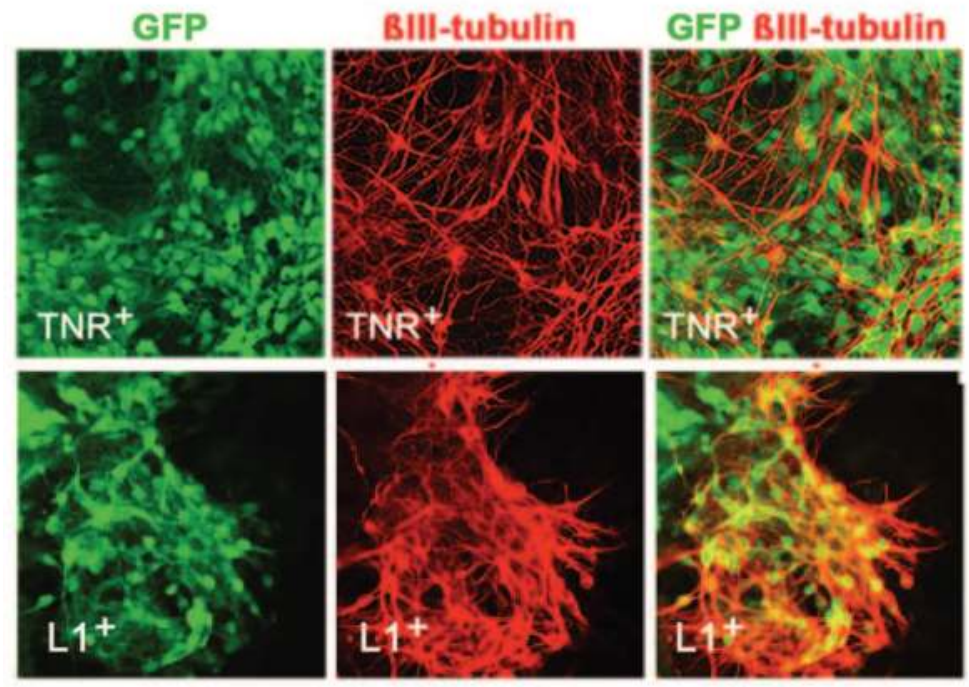

Fig. 1. Tenascin-R (TNR+) and L1 (L1+) overexpressing mouse ES cells differentiate into $\beta$ IIItubulin-positive neurons (red) in vitro. The images in the upper row show cells at the end of differentiation using a 5-stage differentiation protocol, whereas images in the lower row show differentiated cells after prolonged cultivation in vitro, that form so-called substrateadherent embryonic stem cell-derived neural aggregates (SENAs). Both ES cell lines constitutively express green fluorescent protein (GFP; green) for better visualization after transplantation into animal models of disease. Images from Hargus et al., 2008 and Cui et al., 2010 with permission from Stem Cells and Brain 
Furthermore, by extending the time of culture at stage 4 for several weeks without passaging, we were able to derive three-dimensional neural aggregates that predominantly consist of postmitotic neurons and radial glial cells (Dihne et al., 2006). These substrateadherent embryonic stem cell-derived neural aggregates (SENAs) can readily be isolated for transplantation and survive well after engraftment into the adult rodent brain (Dihne et al, 2006; Cui et al., 2010).

ES cells can be easily modified to overexpress genes of interest, which could have beneficial effects on the survival of ES cells and the differentiation of ES cells into certain cell lineages. Therefore, besides applying optimized differentiation protocols, several groups have overexpressed transcription factors in mouse and human ES cells in order to promote the differentiation of ES cells into particular neuronal subtypes. For example, overexpression of the transcription factor pitx-3 (Chung et al., 2005) or the LIM homeodomain transcription factor Imx1a (Friling et al., 2009) in mouse ES cells caused enhanced differentiation into midbrain dopaminergic neurons, which are the cell population at risk in Parkinson's disease. Similarly, mouse ES cells overexpressing the nuclear-receptor-related-factor-1 (nurr1) showed enhanced differentiation into midbrain dopaminergic neurons in vitro and improved functional impairment after transplantation in an animal model of Parkinson`s disease (Kim et al., 2002).

\section{The role of the cell adhesion molecule $L 1$ and the extracellular matrix protein TNR during neuroectodermal differentiation of ES cells in vitro}

Little is known about the effects of an overexpression of neural cell adhesion molecules or extracellular matrix (ECM) proteins in ES cells on their differentiation into postmitotic neurons and about their role in ES cell-mediated regeneration in animal models of neurological diseases. This is quite surprising, given that both groups of recognition molecules have important functions on cellular development and survival both in vitro and in vivo. Indeed, during embryogenesis but also during the entire postnatal life, the specification and integrity of cells is highly dependent on the communication of cells with their surrounding environment through transmembrane glycoproteins on neighboring cells (cell-cell interactions) or through soluble and structural components of the extracellular matrix (cell-matrix interactions). These properties of recognition molecules could have significant implications for cell replacement therapy approaches, since they may help to improve differentiation of ES cells in vitro and may support integration, survival and function of ES cell-derived cells after transplantation into animal models of disease.

We have generated mouse ES cells that overexpress the recognition molecules L1 or TNR and have analyzed several effects of these molecules on ES cell-mediated regeneration in animal models of acute and chronic neurological disorders.

\subsection{The effects of L1 on neuroectodermal differentiation of ES cells in vitro}

L1 is a transmembrane cell surface molecule, which is expressed on postmitotic neurons in the central nervous system (CNS) and is found on Schwann cells in peripheral nerves (Lindner et al., 1983; Rathjen and Schachner, 1984; Moos et al., 1988; Kamiguchi and Yoshihara, 2001). L1 is essential for the development of the central nervous system, as L1 promotes neuronal survival, neuronal migration and neurite outgrowth (Lemmon et al., 1989; Appel et al., 1993; Brummendorf et al., 1998; Kamiguchi and Yoshihara, 2001; Kleene et al., 2001). A lack of L1 results in severe malformations within the CNS such as 
hydrocephalus or hypoplasia or even aplasia of fiber tracts including the corticospinal tract and the corpus callosum (Jouet et al., 1994). Furthermore, L1-deficient mice have a reduced number of hippocampal neurons and anatomical malformations similar to those seen in patients have been described in these animals (Dahme et al., 1997; Demyanenko et al., 1999). Besides its role during development, L1 has important functions in memory acquisition and is known to increase axon guidance and axon myelination after traumatic injury of the CNS and peripheral nervous system (Martini and Schachner, 1988; Zhang et al., 2000; Becker et al., 2004b).

When L1-overexpressing mouse ES cells were differentiated into neuroectodermal cells following the five stage differentiation protocol, the proportion of postmitotic neurons was significantly increased in vitro when compared to cultures consisting of differentiated mouse ES cells that had been transfected with an empty vector (WT ES cells; Bernreuther et al., 2006). This pro-neuronal effect of L1 on cell differentiation, which happened at the expense of differentiation into astrocytic cells, is consistent with previous studies that showed increased neuronal differentiation of somatic neural stem cells when cultured on a surface coated with recombinant L1 (Dihne et al., 2003) or when genetically modified to overexpress L1 protein (own unpublished observations). This pro-neuronal effect could be attributed to homophilic interactions of L1. Furthermore, heterophilic cell-cell interactions through integrins, F3/contactin, NCAM, CD9, and CD24 on other neurons have been described for L1 as well as cell-matrix interactions (Silletti et al., 2000), which could additionally account for the beneficial effects of L1 on neuroectodermal differentiation of ES cells in vitro.

Notably, other neuronal surface molecules besides L1 have been shown to promote neuronal differentiation in vitro, which further supports the hypothesis that an overexpression of neuronal cell adhesion molecules in ES cells is a suitable approach towards their application in vivo. ES cells overexpressing the glycoprotein M6A, which is a cell adhesion molecule expressed on neurons in the CNS, differentiated more efficiently into neurons when compared to non-modified control ES cells (Michibata et al., 2009) and the L1binding partner molecule NCAM significantly increased neuronal differentiation of embryonic neural precursor cells into mature neurons in vitro when added into medium of cultured cells (Shin et al., 2002). However, in contrast to L1, the beneficial effects of ES cells overexpressing these molecules have not been tested in animal models of disease to date.

\subsection{The effects of TNR on neuroectodermal differentiation of ES cells in vitro}

TNR is an ECM protein and is almost exclusively expressed by oligodendrocytes and subpopulations of neurons in the CNS after birth. In white matter, TNR is located at nodes of Ranvier and internodes (ffrench-Constant et al., 1986; Bartsch et al., 1993). In grey matter, TNR is detectable in perineuronal nets that surround inhibitory interneurons and motorneurons and which provide neuroprotective cues to these cells (Angelov et al., 1998; Bruckner et al., 2000; Dityatev et al., 2010). Several, in part opposing functions have been described for TNR and therefore, this molecule was also named janusin adopted from the name of the Latin god Janus, the god with the two faces symbolizing ambivalence (for review see Schachner et al., 1994). For instance, TNR acts as a repellent guidance molecule in the optic nerve of zebrafish (Becker et al., 2003), but mediates the detachment of migrating cells from the RMS within the olfactory bulb in mice, establishing TNR also as an attracting guidance molecule (Saghatelyan et al., 2004). Furthermore, TNR promotes neurite outgrowth in vitro when presented as a smooth substrate (Husmann et al., 1992; Norenberg et al., 1995), but inhibits neurite outgrowth when presented as sharp substrate border (Becker et al., 2004a). 
Similar to L1-overexpressing ES cells, TNR-overexpressing ES cells showed an enhanced neuronal differentiation into postmitotic neurons at the end of differentiation when compared to differentiated mouse ES cells that had been transfected with an empty vector (WT ES cells; Hargus et al., 2008a). It is currently not known why TNR promotes neuronal differentiation of ES cells in vitro but similarly to TNR, a pro-neuronal effect has also been described for tenascin-C, another member of the tenascin family of ECM molecules, which significantly increased neuronal differentiation of embryonic mesencephalic explant cultures when added to the cell culture medium (Marchionini et al., 2003). Interestingly, TNR-deficient mice have reduced numbers of inhibitory interneurons in the motor and sensory cortex, which illustrates a pro-neuronal effect of TNR also in vivo (own unpublished observations).

Notably, extracellular matrix molecules are widely used to promote the differentiation of ES cells into neuroectodermal cells. For example, current differentiation protocols recommend the application of fibronectin and laminin to ES cell-derived neural precursor cells (Lee et al., 2000). Furthermore, culture of differentiating ES cells on substrate-bound poly-Lornithine or soluble Matrigel - a basement membrane extract consisting of collagen IV, heparin sulphate proteoglycans, entactin, and nidogen (Kleinman et al., 1986) - increases neuronal differentiation of ES cells in vitro (Goetz et al., 2006; Ma et al., 2008). It should be mentioned, however, that also inhibiting effects of some extracellular matrix proteins on neuronal differentiation of ES cells have been described. Gelatine - a mixture of collagen components - increases astrocytic but significantly decreases neuronal differentiation of ES cells in vitro (Goetz et al., 2006).

\section{Application of differentiated ES cells and fetal cells in animal models of neurological diseases}

Several studies have shown that the transplantation of differentiated and specialized neurons can lead to functional improvement in animal models of neurological diseases. For instance, neurons isolated from mouse or human embryonic mesencephalon have been widely used for transplantation in the 6-OHDA-lesion rodent animal model of Parkinson's disease (Grealish et al. 2010; Brundin et al., 1986), and human fetal cells from the ventral mesencephalon have also been used in several clinical trials in Parkinson patients, some of which showed significant clinical improvement (Mendez et al., 2005; Astradsson et al., 2008; Mendez et al., 2008; Lindvall and Kokaia, 2009). Similarly, fetal striatal neurons have been successfully transplanted into animal models of Huntington's disease to replace damaged GABAergic medium-sized spiny projection neurons in the host striatum (Isacson et al., 1986; Dunnett and Rosser, 2007), and clinical trials have shown improvement in some of the transplanted patients suffering from Huntington's disease (Philpott et al., 1997; Dunnett and Rosser, 2004).

However, alternative cellular sources are required because of the limited availability of fetal tissue. Due to their ability to generate functional neurons at high numbers in vitro, ES cells constitute a promising cell population for such therapeutic approaches and have been applied in several animal models of neurological diseases after pre-differentiation into desired neuronal phenotypes in vitro. Several studies have shown that transplantation of mouse, primate or human ES cell-derived neural precursor cells or neurons can lead to functional improvement in animal models of Parkinson's disease (Bjorklund et al., 2002; Kim et al., 2002; Ben-Hur et al., 2004; Roy et al., 2006; Sanchez-Pernaute et al., 2008; Yang et 
al., 2008; Cui et al., 2010). Furthermore, differentiated mouse and human ES cells have been successfully applied in animal models of Huntington`s disease (Bernreuther et al., 2006; Dihne et al., 2006; Aubry et al., 2008; Hargus et al., 2008a), stroke (Wei et al., 2005; Buhnemann et al., 2006; Oyamada et al., 2008), and spinal cord injury (Chen et al., 2005; Keirstead et al., 2005; Sharp et al., 2010) to improve different aspects of regeneration. Notably, the American Food and Drug Administration (FDA) has recently for the first time approved a clinical trial on the transplantation of human ES cell-derived oligodendrocyte progenitor cells in patients with acute spinal cord injury conducted by the Geron Corporation. In this context, however, it should be emphasized that the transplantion ES-cell derived cells is associated with a specific risk of teratoma formation due to the presence of undifferentiated ES cells in the cell suspension for transplantation, emphasizing the requirement for efficient cell differentiation in vitro and for thorough cell purification before engraftment. We will focus on this topic at the end of this chapter.

\section{Transplantation of differentiated L1-overexpressing and TNR- overexpressing ES cells in animal models of acute and chronic neurological disorders}

Several challenges are associated with transplantation of ES cell-derived neurons, which determine functional outcomes of a cell replacement therapy. Such critical aspects include an efficient differentiation of ES cells into desired neuronal phenotypes in vitro as described above, sufficient survival of donor cells after transplantation, and efficient integration of transplanted neurons within the host tissue in order to mediate functional graft-host communication. Several studies have described poor survival of ES cell-derived neurons and limited graft-host interactions after transplantation into the adult rodent striatum (Schulz et al., 2004; Yurek and Fletcher-Turner, 2004; Sonntag et al., 2007) and that survival of cells depends on time of injection after injury (Johann et al., 2007; Darsalia et al., 2010).

By overexpressing the recognition molecule L1 in ES cells, we found that in vitro-generated L1-overexpressing SENAs showed two-fold improved survival after transplantation into MPTP-treated Parkinsonian mice when compared to engrafted WT SENAs (Cui et al. 2010). Furthermore, the L1-overexpressing SENAs contained an approximately two-fold increased number of dopaminergic neurons, and engrafted L1-overexpressing cells migrated 2.5x longer distances within the host striatum than wt cells. Also, transplanted L1overexpressing SENAs rescued a higher number of endogenous imperilled midbrain dopaminergic neurons and improved functional recovery when compared to engrafted differentiated WT SENAs (Cui et al. 2010). In two other studies, we applied the 5-stage differentiation protocol to L1-overexpressing and WT ES cells, which were transplanted into the quinolinic-acid mouse model of Huntington's disease (Bernreuther et al., 2006) and into an animal model of acute spinal cord injury (Chen et al., 2005). In the former study, the L1overexpressing grafts contained a higher number of surviving GABAergic neurons and L1overexpressing cells migrated $3 \times$ longer distances within the host striatum when compared to WT cells. Importantly, L1-overexpressing ES cell-derived cells showed functional effects on apomorphine-induced rotational asymmetry in these quinolinic acid-lesioned animals in contrast to engrafted WT control cells (Bernreuther et al., 2006). In line with these findings, differentiated L1-overexpressing ES cells showed robust survival and migrated up to 700 $\mu \mathrm{m}$ in an animal model of acute spinal cord injury, while only few differentiated WT ES cells survived the first few weeks after transplantation into the spinal cord (Chen et al., 2005). 
Similar to L1-overexpressing ES cell grafts, transplants consisting of TNR-overexpressing ES cells, differentiated according to the 5-stage differentiation protocol, contained a two- to three-fold higher number of surviving GABAergic neurons in the quinolinic acid-lesioned mouse striatum when compared to WT ES cells (Hargus et al., 2008a). However, in contrast to engrafted L1-overexpressing cells, TNR-overexpressing ES cells showed slightly decreased migration into the host striatum when compared to WT ES cells, but attracted host-derived neuroblasts from the subventricular zone (SVZ) and the rostral migratory stream (RMS) leading to the recruitment of host-derived newborn neurons within the grafted area (Hargus et al., 2008a).

\subsection{The influence of L1 and TNR on survival of transplanted cells}

Most cells die shortly after transplantation into the adult brain and spinal cord probably due to hypoxia, reduced supply of trophic factors and immune responses. It has been proposed that also limited cell-cell and cell-matrix interactions account for cell death after transplantation into the CNS (Marchionini et al., 2003). Indeed, cell apoptosis can be induced by lack of structural support from surrounding neighboring cells and from the extracellular environment (Raff, 1992; Meredith et al., 1993; Frisch and Francis, 1994). This kind of apoptosis has been shown as early as during the trituration of neural stem cells in vitro prior to transplantation (Schierle et al., 1999). Therefore, stable expression of surface or matrix molecules in engrafted cells might help to increase cell-cell contacts and cellular survival. Candidate molecules include NCAM and L1, since both recognition molecules have neuroprotective effects on dopaminergic neurons in vitro (Hulley et al., 1998; Ditlevsen et al., 2007), and mechanisms for L1-mediated neuroprotection have been described, which include inhibition of caspase-3 and increased phosphorylation of extracellular signal-related kinases 1/2, Akt and Bad (Loers et al., 2005). Increased L1-mediated cell-cell interactions in grafts could explain why L1-overexpressing cells contained a reduced number of caspasepositive apoptotic cells and an increased number of surviving dopaminergic neurons after engraftment into Parkinsonian mice (Cui et al. 2010), and why L1-overexpressing ES cells survived after transplantation into the injured spinal cord while only few WT ES cellderived cells were detectable (Chen et al., 2005). Therefore, the microenvironment around grafted cells seems to further influence those mechanisms of cell survival, which are mediated by cell surface molecules.

Since ECM proteins provide structural support to cells and may help to trap and store growth factors, several groups have analyzed the effect of co-delivery of cells and matrix proteins on the survival and function of these cells in the brain but also outside the CNS. When rat cardiomyoblasts were engrafted in collagen matrices into a rat model of myocardial infarction, larger grafts and an improved ventricular heart function were observed in these animals (Kutschka et al., 2006). Similarly, human ES-cell derived cardiomyocytes survived better in infarcted rat hearts when co-delivered with a factorenriched Matrigel matrix (Laflamme et al., 2007). The addition of the ECM protein tenascin$C$ to a single cell suspension of fetal mesencephalic neurons before transplantation significantly increased the survival of graft-derived dopaminergic neurons, when engrafted at low density in a rat model of Parkinson's disease (Marchionini et al., 2003). This study also showed that the cell density of engrafted cells is a critical parameter for the impact of co-delivered ECM molecules on the survival of implanted cells, as tenascin-C did not 
influence cell survival in grafts with high cell density. Using a similar high-cell-density approach, we could show that grafts consisting of differentiated TNR-overexpressing ES cells contained increased numbers of surviving GABAergic neurons in a mouse model of Huntington's disease (Hargus et al., 2008a) when compared to WT ES cells. However, this effect is most likely a result of the positive effect of TNR on the in vitro-differentiation of ES cells into postmitotic neurons rather than a result of increased cell survival (as similarly seen for $\mathrm{L}^{+}$grafts in the same animal model), since the graft sizes were not altered by the presence of TNR. It will be very interesting to determine how different densities of TNRoverexpressing ES cells for transplantation influence cell survival and function in this and other animal models of neurological diseases.

\subsection{The role of the recognition molecules L1 and TNR on cell migration in animal models of neurological disorders}

Successful outcomes of a cell therapy in neurological diseases depend on sufficient interaction of engrafted neurons with host-derived cells. Such interaction could lead to functional integration of graft-derived neurons into endogenous neuronal circuitries, mediate important structural and trophic support to imperilled host-derived neurons and result in the mobilization of endogenous host-derived neural progenitor cells, which in turn might support graft-mediated regeneration within the host brain.

Enhanced migration of implanted cells into the host tissue could be beneficial for the integration of engrafted cells, since this process favors a higher degree of functional connectivity to host circuitries (Dunnett and Rosser, 2007). It is well known that engrafted differentiated ES cells show only poor migration in the recipient brain in contrast to implanted fetal neural progenitor cells (Englund et al., 2002; Dunnett and Rosser, 2007). By transplanting differentiated ES cells as SENAs instead of single cells, we could show that the migration of engrafted ES cells into the rodent striatum was significantly enhanced possibly due to the altered microenvironment provided by different cell-cell and cell-matrix interactions (Dihne et al., 2006). Furthermore, an overexpression of L1 in engrafted ES cellderived cells resulted in significantly enhanced migration into the host striatum in both, MPTP- and quinolinic acid-lesioned Parkinsonian and Huntington mice (Bernreuther et al., 2006; Cui et al., 2010). In addition, differentiated L1-overexpressing ES cells migrated rostrally and caudally from the lesion site when transplanted in an animal model of acute spinal cord injury, while WT ES cells remained at the injection site (Chen et al., 2005). Importantly, the engrafted L1-overexpressing cells showed close proximity to re-growing corticospinal tract axons, which were guided into and also beyond the lesion site in the injured spinal cord. Similar beneficial effects of L1 on axonal outgrowth of corticospinal neurons have been decribed after infusion of soluble Fc-tagged L1 into the lesioned spinal cord, which resulted in behavioral recovery in most of the L1-Fc-treated animals (Roonprapunt et al., 2003).

Overexpression of polysialic acid (PSA), a carbohydrate polymer attached to the neural cell adhesion molecule NCAM, which was achieved by transduction of ES cell-derived cells with retroviruses encoding the polysialyltransferase STX, modified the susceptibility of differentiated ES cells to cytokines after transplantation into the rodent brain thereby influencing migration (Glaser et al., 2007). Since these PSA-expressing ES cells were transplanted into the striatum of healthy unlesioned rats, it is not known how these cells influence function in animal models of neurological diseases. However, such transplantation 
studies could be very promising given that PSA glycomimetica promote functional recovery in mice after peripheral nerve injury (Mehanna et al., 2009) and spinal cord compression (Mehanna et al. 2010).

ECM molecules can act as attractant or repellent guidance molecules and both functions have been described for TNR in vitro and in vivo (Schachner et al., 1994; Jones and Jones, 2000). Differentiated TNR-overexpressing ES cells migrated shorter distances in vitro and after transplantation into the striatum of quinolinic acid-lesioned mice in vivo when compared to WT cells (Hargus et al., 2008a). However, despite reduced migration of engrafted cells, TNR-overexpressing ES cells showed a tendency towards increased coverage with host-derived synaptic boutons (Hargus et al., 2008a), reflecting increased synaptic input from host-derived neurons towards engrafted cells. This finding goes in line with the reduced density and abnormal structure of symmetrical synapses in TNR-deficient mice (Nikonenko et al., 2003; Apostolova et al., 2006). The generally low degree of synaptic coverage of engrafted ES cell-derived neurons (less than $6 \%$ of all engrafted cells for both TNR-overexpressing and WT cells), could explain, however, why engrafted rats did not show reduction in apomorphine-induced rotational asymmetry (Hargus et al., 2008a).

\subsection{The role of the recognition molecules L1 and TNR on endogenous neurogenesis and neuroprotection in animal models of neurological disorders}

The TNR protein secreted by implanted TNR-overexpressing cells had interesting positive effects on graft-host interactions, as host-derived doublecortin-positive neuroblasts were attracted by engrafted TNR-overexpressing ES cell-derived cells and migrated from the SVZ and the RMS towards and into the grafted area. This effect was sustained for at least 2 months after transplantation (Hargus et al., 2008a). This attractant effect of ectopically presented TNR on endogenous migrating neuroblasts from the SVZ, that migrate toward the olfactory bulb but no other brain regions under physiological conditions (Luskin, 1993; Lois and Alvarez-Buylla, 1994), has been previously described after transplantation of nonneuronal TNR-overexpressing fibroblast-like cells into the adult forebrain in close proximity to the RMS (Saghatelyan et al., 2004) and is in line with the observations that TNR serves as a detachment signal for migrating cells in the adult olfactory bulb (Saghatelyan et al., 2004) and developing cerebellar cortex (Husmann et al., 1992). Furthermore and in line with our observations on enhanced TNR-mediated neuronal differentiation of ES cells in vitro, we found that TNR-overexpressing ES cell-derived cells promoted the generation of newborn host-derived neurons in the grafted area, and the degree of this recruitment of endogenous neurons was three-fold higher than in grafts consisting of WT ES cell-derived cells (Hargus et al., 2008a).

It remains open to which extent a recruitment of migrating or in situ-generated host-derived neural precursor cells or newborn neurons supports regeneration in the adult lesioned brain. However, a recruitment of endogenous neural progenitor cells from the SVZ into lesioned areas has been described in several animal models after ischemic (Arvidsson et al., 2002; Nakatomi et al., 2002; Parent et al., 2002), physical (Magavi et al., 2000) or excitotoxic (Tattersfield et al., 2004) brain lesions, and differentiation of these recruited precursor cells into neurons with adequate phenotypes has been shown in many of these studies (Magavi et al., 2000; Arvidsson et al., 2002; Nakatomi et al.; Parent et al., 2002).

In this context it should be noted, that other beneficial molecules including glial cell linederived neurotrophic factor (GDNF) and brain-derived neurotrophic factor (BDNF) could 
also be considered for overexpression in ES cells to improve regeneration in animal models of neurological diseases. Indeed, intraventricular application of BDNF enhanced neurogenesis in the SVZ (Zigova et al., 1998) and induced migration of neural progenitor cells from the SVZ into adjacent non-neurogenic areas in the adult brain (Benraiss et al., 2001; Pencea et al., 2001). Furthermore, both BDNF and GDNF are used in established protocols for the differentiation of human ES cells into dopaminergic neurons in vitro (Perrier et al., 2004; Sonntag et al., 2007; Cooper et al., 2010) and have neuroprotective effects on endogenous neurons in animal models of neurodegenerative diseases (Grondin and Gash, 1998; Zuccato and Cattaneo, 2009). Interestingly, BDNF (Cassens et al. 2010) and GDNF (Nielsen et al., 2009) have been shown to be functionally connected to neural cell adhesion molecules and thus, beneficial effects of overexpression of these neurotrophins might be mediated by neural cell adhesion molecules and therefore, overexpression of cell adhesion molecules instead of neurotrophins might prevent potential adverse effects of neurotrophin overexpression such as induction of neuropathic pain (Geng et al., 2010).

Similar neuroprotective effects on endogenous host-derived neurons are mediated by the transplantation of neural stem cells into rodent animal models of Parkinson's disease (Ourednik et al., 2002; Yasuhara et al., 2006) or spinal cord injury (Teng et al., 2002), probably due to neuroprotective factors secreted by engrafted cells. Interestingly, an overexpression of L1 in neural stem cells improved their distribution within the host midbrain and rescued about $1.5 \times$ more host-derived imperilled dopaminergic neurons after transplantation into MPTP-lesioned transgenic L1-overexpressing Parkinsonian mice, when compared with engrafted WT neural stem cells (Ourednik et al., 2009). This finding demonstrates that a recognition molecule can positively influence survival of endogenous neurons and led us to analyze the effects of overexpression of L1 in engrafted differentiated ES cells on host-derived dopaminergic neurons in the MPTP-lesion mouse model of Parkinson's disease (Cui et al. 2010). L1-overexpressing SENAs transplanted in close proximity to the substantia nigra increased the number of host-derived dopaminergic neurons and enhanced striatal dopamine levels after intrastriatal transplantation, demonstrating neuroprotective effects of L1-overexpressing SENAs, which were not found after transplantation of WT SENAs.

\section{Methods to purify ES cell-derived cells for transplantation into animal models of neurological diseases}

Before differentiated ES cells can be considered for any clinical application, a purification of ES cell-derived cells is required in order to enrich the cellular phenotypes of interest and to remove residual undifferentiated cells.

Although ES cells can be efficiently differentiated into a variety of desired cell types in vitro, current differentiation protocols do not generate a homogenous population of cells. As described above, a directed differentiation of ES cells into neuroectodermal cells can significantly enhance the number of functional neurons with specific neurotransmitter profiles in vitro but other neural phenotypes and even cells of other germ layer origins commonly contaminate the final cell population. This finding has an important impact on ES cell-based replacement therapies, since unwanted cellular phenotypes could significantly reduce the efficiency of such approaches. For instance, fetal mesencephalic tissue 
transplanted into Parkinsonian animals or Parkinson patients can cause side effects such as graft-induced dyskinesia, which has been discussed to be a result of the heterogeneity of engrafted cells and the presence of donor-derived serotoninergic neurons in grafts (Carlsson et al., 2007; Allan et al., 2010). Most importantly, undifferentiated ES cells can lead to the formation of teratomas consisting of cells of all three germ layers after transplantation.

Cell separation methods include immunopanning, magnetic-associated cell sorting (MACS) or fluorescence-activated cell sorting (FACS), which have been applied on differentiated ES cells.

Immunopanning of cells is achieved by plating cells on a surface coated with an antibody directed against specific epitopes of interest. By applying this method involving L1 antibody-coated surfaces, mouse ES cell-derived neurons have been isolated at high purity, which formed excitatory and inhibitory synapses and were electrically excitable after replating (Jungling et al., 2003). Similarly, ES cell-derived neural precursor cells have been efficiently purified after immunopanning for PSA-NCAM (Schmandt et al., 2005).

MACS purification for cell surface molecules has been applied on both, mouse (David et al., 2005) and human (Pruszak et al., 2007) ES cell-derived cells and an enrichment for labelled cells was described in these studies. However, the purity of MACS-sorted cells was lower compared to FACS-sorting procedures on the same cell population (Pruszak et al., 2007). Furthermore, a significant enrichment of neural cells was achieved by FACS-sorting differentiated ES cell cultures for single neural cell adhesion molecules such as NCAM (CD56) or CD146 (Pruszak et al., 2007), or for a combination of cell surface antigens including CD15, CD24 and CD29 (Pruszak et al., 2009). To determine safety and efficiency of a FACS-sorting procedure for a neural cell adhesion molecule, NCAM-FACS-purified human pluripotent stem cell-derived neural cells were transplanted in an animal model of Parkinson's disease (Hargus et al. 2010). The FACS-purified cells survived and showed functional effects on rotational asymmetry in these animals, while formation of teratomas was not observed. The same study demonstrated that human pluripotent stem cell-derived neurons express the recognition molecule L1 at high levels (Hargus et al., 2010). Therefore, L1 could also be a suitable candidate molecule for FACS purification experiments with the advantage that postmitotic neurons could also be separated from immature L1-negative but NCAM-positive neural precursor cells and astrocytic cells for transplantation.

\section{Conclusion}

In this chapter, we provided examples that an overexpression of recognition molecules in ES cells can influence different aspects of stem cell-mediated regeneration in animal models of acute and chronic neurological disorders including cellular differentiation, migration, recruitment of endogenous neural cells, neuroprotection, and replacement of imperilled host-derived neurons. These findings encourage further investigation of supporting functions of recognition molecules for stem cell-based therapeutic approaches in human diseases. Furthermore, several studies on cell separation of ES cell-derived neurons preventing the formation of teratomas show important progress towards an application of ES cell-derived cells in patients with neurological disorders, and encourage further refinements of these separation techniques for a potential standardized ES cell-based cell therapy. 


\section{Acknowledgements}

The authors are grateful to Melitta Schachner for discussion and editing of the manuscript.

\section{References}

Allan LE, Petit GH, Brundin P (2010) Cell transplantation in Parkinson's disease: problems and perspectives. Curr Opin Neurol 23:426-432.

Angelov DN, Walther M, Streppel M, Guntinas-Lichius O, Neiss WF, Probstmeier R, Pesheva P (1998) Tenascin- $R$ is antiadhesive for activated microglia that induce downregulation of the protein after peripheral nerve injury: a new role in neuronal protection. J Neurosci 18:6218-6229.

Apostolova I, Irintchev A, Schachner M (2006) Tenascin-R restricts posttraumatic remodeling of motoneuron innervation and functional recovery after spinal cord injury in adult mice. J Neurosci 26:7849-7859.

Appel F, Holm J, Conscience JF, Schachner M (1993) Several extracellular domains of the neural cell adhesion molecule L1 are involved in neurite outgrowth and cell body adhesion. J Neurosci 13:4764-4775.

Arvidsson A, Collin T, Kirik D, Kokaia Z, Lindvall O (2002) Neuronal replacement from endogenous precursors in the adult brain after stroke. Nat Med 8:963-970.

Astradsson A, Cooper O, Vinuela A, Isacson O (2008) Recent advances in cell-based therapy for Parkinson disease. Neurosurg Focus 24:E6.

Aubry L, Bugi A, Lefort N, Rousseau F, Peschanski M, Perrier AL (2008) Striatal progenitors derived from human ES cells mature into DARPP32 neurons in vitro and in quinolinic acid-lesioned rats. Proc Natl Acad Sci U S A 105:16707-16712.

Barberi T, Klivenyi P, Calingasan NY, Lee H, Kawamata H, Loonam K, Perrier AL, Bruses J, Rubio ME, Topf N, Tabar V, Harrison NL, Beal MF, Moore MA, Studer L (2003) Neural subtype specification of fertilization and nuclear transfer embryonic stem cells and application in parkinsonian mice. Nat Biotechnol 21:1200-1207.

Bartsch U, Pesheva P, Raff M, Schachner M (1993) Expression of janusin (J1-160/180) in the retina and optic nerve of the developing and adult mouse. Glia 9:57-69.

Becker CG, Schweitzer J, Feldner J, Becker T, Schachner M (2003) Tenascin-R as a repellent guidance molecule for developing optic axons in zebrafish. J Neurosci 23:6232-6237.

Becker CG, Schweitzer J, Feldner J, Schachner M, Becker T (2004a) Tenascin-R as a repellent guidance molecule for newly growing and regenerating optic axons in adult zebrafish. Mol Cell Neurosci 26:376-389.

Becker CG, Lieberoth BC, Morellini F, Feldner J, Becker T, Schachner M (2004b) L1.1 is involved in spinal cord regeneration in adult zebrafish. J Neurosci 24:7837-7842.

Ben-Hur T, Idelson M, Khaner H, Pera M, Reinhartz E, Itzik A, Reubinoff BE (2004) Transplantation of human embryonic stem cell-derived neural progenitors improves behavioral deficit in Parkinsonian rats. Stem Cells 22:1246-1255.

Benraiss A, Chmielnicki E, Lerner K, Roh D, Goldman SA (2001) Adenoviral brain-derived neurotrophic factor induces both neostriatal and olfactory neuronal recruitment from endogenous progenitor cells in the adult forebrain. J Neurosci 21:6718-6731. 
Bernreuther C, Dihne M, Johann V, Schiefer J, Cui Y, Hargus G, Schmid JS, Xu J, Kosinski CM, Schachner M (2006) Neural cell adhesion molecule L1-transfected embryonic stem cells promote functional recovery after excitotoxic lesion of the mouse striatum. J Neurosci 26:11532-11539.

Bjorklund LM, Sanchez-Pernaute R, Chung S, Andersson T, Chen IY, McNaught KS, Brownell AL, Jenkins BG, Wahlestedt C, Kim KS, Isacson O (2002) Embryonic stem cells develop into functional dopaminergic neurons after transplantation in a Parkinson rat model. Proc Natl Acad Sci U S A 99:2344-2349.

Bruckner G, Grosche J, Schmidt S, Hartig W, Margolis RU, Delpech B, Seidenbecher CI, Czaniera R, Schachner M (2000) Postnatal development of perineuronal nets in wild-type mice and in a mutant deficient in tenascin-R. J Comp Neurol 428:616-629.

Brummendorf T, Kenwrick S, Rathjen FG (1998) Neural cell recognition molecule L1: from cell biology to human hereditary brain malformations. Curr Opin Neurobiol 8:8797.

Brundin P, Nilsson OG, Strecker RE, Lindvall O, Astedt B, Bjorklund A (1986) Behavioural effects of human fetal dopamine neurons grafted in a rat model of Parkinson's disease. Exp Brain Res 65:235-240.

Buhnemann C, Scholz A, Bernreuther C, Malik CY, Braun H, Schachner M, Reymann KG, Dihne M (2006) Neuronal differentiation of transplanted embryonic stem cellderived precursors in stroke lesions of adult rats. Brain 129:3238-3248.

Carlsson T, Carta M, Winkler C, Bjorklund A, Kirik D (2007) Serotonin neuron transplants exacerbate L-DOPA-induced dyskinesias in a rat model of Parkinson's disease. J Neurosci 27:8011-8022.

Cassens C, Kleene R, Xiao MF, Friedrich C, Dityateva G, Schafer-Nielsen C, Schachner M (2010) Binding of the receptor tyrosine kinase TrkB to the neural cell adhesion molecule (NCAM) regulates phosphorylation of NCAM and NCAM-dependent neurite outgrowth. J Biol Chem 285:28959-28967.

Chen J, Bernreuther C, Dihne M, Schachner M (2005) Cell adhesion molecule 11-transfected embryonic stem cells with enhanced survival support regrowth of corticospinal tract axons in mice after spinal cord injury. J Neurotrauma 22:896-906.

Chung S, Hedlund E, Hwang M, Kim DW, Shin BS, Hwang DY, Jung Kang U, Isacson O, Kim KS (2005) The homeodomain transcription factor Pitx3 facilitates differentiation of mouse embryonic stem cells into AHD2-expressing dopaminergic neurons. Mol Cell Neurosci 28:241-252.

Cooper O, Hargus G, Deleidi M, Blak A, Osborn T, Marlow E, Lee K, Levy A, Perez-Torres E, Yow A, Isacson O (2010) Differentiation of human ES and Parkinson's disease iPS cells into ventral midbrain dopaminergic neurons requires a high activity form of $\mathrm{SHH}, \mathrm{FGF} 8 \mathrm{a}$ and specific regionalization by retinoic acid. Mol Cell Neurosci 45(3):258-66

Cui YF, Hargus G, Xu JC, Schmid JS, Shen YQ, Glatzel M, Schachner M, Bernreuther C (2010) Embryonic stem cell-derived L1 overexpressing neural aggregates enhance recovery in Parkinsonian mice. Brain 133:189-204. 
Dahme M, Bartsch U, Martini R, Anliker B, Schachner M, Mantei N (1997) Disruption of the mouse L1 gene leads to malformations of the nervous system. Nat Genet 17:346349.

Darsalia V, Allison SJ, Cusulin C, Monni E, Kuzdas D, Kallur T, Lindvall O, Kokaia Z (2010) Cell number and timing of transplantation determine survival of human neural stem cell grafts in stroke-damaged rat brain. J Cereb Blood Flow Metab.

David R, Groebner M, Franz WM (2005) Magnetic cell sorting purification of differentiated embryonic stem cells stably expressing truncated human CD4 as surface marker. Stem Cells 23:477-482.

Demyanenko GP, Tsai AY, Maness PF (1999) Abnormalities in neuronal process extension, hippocampal development, and the ventricular system of L1 knockout mice. J Neurosci 19:4907-4920.

Dihne M, Bernreuther C, Sibbe M, Paulus W, Schachner M (2003) A new role for the cell adhesion molecule L1 in neural precursor cell proliferation, differentiation, and transmitter-specific subtype generation. J Neurosci 23:6638-6650.

Dihne M, Bernreuther C, Hagel C, Wesche KO, Schachner M (2006) Embryonic stem cellderived neuronally committed precursor cells with reduced teratoma formation after transplantation into the lesioned adult mouse brain. Stem Cells 24:1458-1466.

Ditlevsen DK, Berezin V, Bock E (2007) Signalling pathways underlying neural cell adhesion molecule-mediated survival of dopaminergic neurons. Eur J Neurosci 25:1678-1684.

Dityatev A, Seidenbecher CI, Schachner M (2010) Compartmentalization from the outside: the extracellular matrix and functional microdomains in the brain. Trends Neurosci.

Dunnett SB, Rosser AE (2004) Cell therapy in Huntington's disease. NeuroRx 1:394-405.

Dunnett SB, Rosser AE (2007) Cell transplantation for Huntington's disease Should we continue? Brain Res Bull 72:132-147.

Englund U, Fricker-Gates RA, Lundberg C, Bjorklund A, Wictorin K (2002) Transplantation of human neural progenitor cells into the neonatal rat brain: extensive migration and differentiation with long-distance axonal projections. Exp Neurol 173:1-21.

Evans MJ, Kaufman MH (1981) Establishment in culture of pluripotential cells from mouse embryos. Nature 292:154-156.

Ffrench-Constant C, Miller RH, Kruse J, Schachner M, Raff MC (1986) Molecular specialization of astrocyte processes at nodes of Ranvier in rat optic nerve. J Cell Biol 102:844-852.

Friling S, Andersson E, Thompson LH, Jonsson ME, Hebsgaard JB, Nanou E, Alekseenko Z, Marklund U, Kjellander S, Volakakis N, Hovatta O, El Manira A, Bjorklund A, Perlmann T, Ericson J (2009) Efficient production of mesencephalic dopamine neurons by Lmx1a expression in embryonic stem cells. Proc Natl Acad Sci U S A 106:7613-7618.

Frisch SM, Francis H (1994) Disruption of epithelial cell-matrix interactions induces apoptosis. J Cell Biol 124:619-626.

Geng SJ, Liao FF, Dang WH, Ding X, Liu XD, Cai J, Han JS, Wan Y, Xing GG (2010) Contribution of the spinal cord BDNF to the development of neuropathic pain by 
activation of the NR2B-containing NMDA receptors in rats with spinal nerve ligation. Exp Neurol 222:256-266.

Glaser T, Brose C, Franceschini I, Hamann K, Smorodchenko A, Zipp F, Dubois-Dalcq M, Brustle O (2007) Neural cell adhesion molecule polysialylation enhances the sensitivity of embryonic stem cell-derived neural precursors to migration guidance cues. Stem Cells 25:3016-3025.

Goetz AK, Scheffler B, Chen HX, Wang S, Suslov O, Xiang H, Brustle O, Roper SN, Steindler DA (2006) Temporally restricted substrate interactions direct fate and specification of neural precursors derived from embryonic stem cells. Proc Natl Acad Sci U S A 103:11063-11068.

Grealish S, Jonsson ME, Li M, Kirik D, Bjorklund A, Thompson LH (2010) The A9 dopamine neuron component in grafts of ventral mesencephalon is an important determinant for recovery of motor function in a rat model of Parkinson's disease. Brain 133:482495.

Grondin R, Gash DM (1998) Glial cell line-derived neurotrophic factor (GDNF): a drug candidate for the treatment of Parkinson's disease. J Neurol 245:P35-42.

Guan K, Rohwedel J, Wobus AM (1999) Embryonic stem cell differentiation models: cardiogenesis, myogenesis, neurogenesis, epithelial and vascular smooth muscle cell differentiation in vitro. Cytotechnology 30:211-226.

Hargus G, Cui Y, Schmid JS, Xu J, Glatzel M, Schachner M, Bernreuther C (2008a) Tenascin$\mathrm{R}$ promotes neuronal differentiation of embryonic stem cells and recruitment of host-derived neural precursor cells after excitotoxic lesion of the mouse striatum. Stem Cells 26:1973-1984.

Hargus G, Kist R, Kramer J, Gerstel D, Neitz A, Scherer G, Rohwedel J (2008b) Loss of Sox9 function results in defective chondrocyte differentiation of mouse embryonic stem cells in vitro. Int J Dev Biol 52:323-332.

Hargus G, Cooper O, Deleidi M, Levy A, Lee K, Marlow E, Yow A, Soldner F, Hockemeyer D, Hallett PJ, Osborn T, Jaenisch R, Isacson O (2010) Differentiated Parkinson patient-derived induced pluripotent stem cells grow in the adult rodent brain and reduce motor asymmetry in Parkinsonian rats. Proc Natl Acad Sci U S A 107:1592115926.

Hegert C, Kramer J, Hargus G, Muller J, Guan K, Wobus AM, Muller PK, Rohwedel J (2002) Differentiation plasticity of chondrocytes derived from mouse embryonic stem cells. J Cell Sci 115:4617-4628.

Hulley P, Schachner M, Lubbert H (1998) L1 neural cell adhesion molecule is a survival factor for fetal dopaminergic neurons. J Neurosci Res 53:129-134.

Husmann K, Faissner A, Schachner M (1992) Tenascin promotes cerebellar granule cell migration and neurite outgrowth by different domains in the fibronectin type III repeats. J Cell Biol 116:1475-1486.

Isacson O, Dunnett SB, Bjorklund A (1986) Graft-induced behavioral recovery in an animal model of Huntington disease. Proc Natl Acad Sci U S A 83:2728-2732.

Itsykson P, Ilouz N, Turetsky T, Goldstein RS, Pera MF, Fishbein I, Segal M, Reubinoff BE (2005) Derivation of neural precursors from human embryonic stem cells in the presence of noggin. Mol Cell Neurosci 30:24-36. 
Johann V, Schiefer J, Sass C, Mey J, Brook G, Kruttgen A, Schlangen C, Bernreuther C, Schachner M, Dihne M, Kosinski CM (2007) Time of transplantation and cell preparation determine neural stem cell survival in a mouse model of Huntington's disease. Exp Brain Res 177:458-470.

Jones FS, Jones PL (2000) The tenascin family of ECM glycoproteins: structure, function, and regulation during embryonic development and tissue remodeling. Dev Dyn 218:235-259.

Jouet M, Rosenthal A, Armstrong G, MacFarlane J, Stevenson R, Paterson J, Metzenberg A, Ionasescu V, Temple K, Kenwrick S (1994) X-linked spastic paraplegia (SPG1), MASA syndrome and X-linked hydrocephalus result from mutations in the L1 gene. Nat Genet 7:402-407.

Jungling K, Nagler K, Pfrieger FW, Gottmann K (2003) Purification of embryonic stem cellderived neurons by immunoisolation. FASEB J 17:2100-2102.

Kamiguchi H, Yoshihara F (2001) The role of endocytic 11 trafficking in polarized adhesion and migration of nerve growth cones. J Neurosci 21:9194-9203.

Kawasaki H, Suemori H, Mizuseki K, Watanabe K, Urano F, Ichinose H, Haruta M, Takahashi M, Yoshikawa K, Nishikawa S, Nakatsuji N, Sasai Y (2002) Generation of dopaminergic neurons and pigmented epithelia from primate ES cells by stromal cell-derived inducing activity. Proc Natl Acad Sci U S A 99:1580-1585.

Keirstead HS, Nistor G, Bernal G, Totoiu M, Cloutier F, Sharp K, Steward O (2005) Human embryonic stem cell-derived oligodendrocyte progenitor cell transplants remyelinate and restore locomotion after spinal cord injury. J Neurosci 25:46944705.

Kim JH, Auerbach JM, Rodriguez-Gomez JA, Velasco I, Gavin D, Lumelsky N, Lee SH, Nguyen J, Sanchez-Pernaute R, Bankiewicz K, McKay R (2002) Dopamine neurons derived from embryonic stem cells function in an animal model of Parkinson's disease. Nature 418:50-56.

Kleene R, Yang H, Kutsche M, Schachner M (2001) The neural recognition molecule L1 is a sialic acid-binding lectin for CD24, which induces promotion and inhibition of neurite outgrowth. J Biol Chem 276:21656-21663.

Kleinman HK, McGarvey ML, Hassell JR, Star VL, Cannon FB, Laurie GW, Martin GR (1986) Basement membrane complexes with biological activity. Biochemistry 25:312-318.

Kutschka I, Chen IY, Kofidis T, Arai T, von Degenfeld G, Sheikh AY, Hendry SL, Pearl J, Hoyt G, Sista R, Yang PC, Blau HM, Gambhir SS, Robbins RC (2006) Collagen matrices enhance survival of transplanted cardiomyoblasts and contribute to functional improvement of ischemic rat hearts. Circulation 114:I167-173.

Laflamme MA, Chen KY, Naumova AV, Muskheli V, Fugate JA, Dupras SK, Reinecke H, Xu C, Hassanipour M, Police S, O'Sullivan C, Collins L, Chen Y, Minami E, Gill EA, Ueno S, Yuan C, Gold J, Murry CE (2007) Cardiomyocytes derived from human embryonic stem cells in pro-survival factors enhance function of infarcted rat hearts. Nat Biotechnol 25:1015-1024.

Lee SH, Lumelsky N, Studer L, Auerbach JM, McKay RD (2000) Efficient generation of midbrain and hindbrain neurons from mouse embryonic stem cells. Nat Biotechnol 18:675-679. 
Lemmon V, Farr KL, Lagenaur C (1989) L1-mediated axon outgrowth occurs via a homophilic binding mechanism. Neuron 2:1597-1603.

Lindner J, Rathjen FG, Schachner M (1983) L1 mono- and polyclonal antibodies modify cell migration in early postnatal mouse cerebellum. Nature 305:427-430.

Lindvall O, Kokaia Z (2009) Prospects of stem cell therapy for replacing dopamine neurons in Parkinson's disease. Trends Pharmacol Sci 30:260-267.

Loers G, Chen S, Grumet M, Schachner M (2005) Signal transduction pathways implicated in neural recognition molecule L1 triggered neuroprotection and neuritogenesis. J Neurochem 92:1463-1476.

Lois C, Alvarez-Buylla A (1994) Long-distance neuronal migration in the adult mammalian brain. Science 264:1145-1148.

Luskin MB (1993) Restricted proliferation and migration of postnatally generated neurons derived from the forebrain subventricular zone. Neuron 11:173-189.

Ma W, Tavakoli T, Derby E, Serebryakova Y, Rao MS, Mattson MP (2008) Cell-extracellular matrix interactions regulate neural differentiation of human embryonic stem cells. BMC Dev Biol 8:90.

Magavi SS, Leavitt BR, Macklis JD (2000) Induction of neurogenesis in the neocortex of adult mice. Nature 405:951-955.

Marchionini DM, Collier TJ, Camargo M, McGuire S, Pitzer M, Sortwell CE (2003) Interference with anoikis-induced cell death of dopamine neurons: implications for augmenting embryonic graft survival in a rat model of Parkinson's disease. J Comp Neurol 464:172-179.

Martin GR (1981) Isolation of a pluripotent cell line from early mouse embryos cultured in medium conditioned by teratocarcinoma stem cells. Proc Natl Acad Sci U S A 78:7634-7638.

Martini R, Schachner M (1988) Immunoelectron microscopic localization of neural cell adhesion molecules (L1, N-CAM, and myelin-associated glycoprotein) in regenerating adult mouse sciatic nerve. J Cell Biol 106:1735-1746.

Maye P, Becker S, Kasameyer E, Byrd N, Grabel L (2000) Indian hedgehog signaling in extraembryonic endoderm and ectoderm differentiation in ES embryoid bodies. Mech Dev 94:117-132.

Mehanna A, Jakovcevski I, Acar A, Xiao M, Loers G, Rougon G, Irintchev A, Schachner M (2010) Polysialic acid glycomimetic promotes functional recovery and plasticity after spinal cord injury in mice. Mol Ther 18:34-43.

Mehanna A, Mishra B, Kurschat N, Schulze C, Bian S, Loers G, Irintchev A, Schachner M (2009) Polysialic acid glycomimetics promote myelination and functional recovery after peripheral nerve injury in mice. Brain 132:1449-1462.

Mendez I, Sanchez-Pernaute R, Cooper O, Vinuela A, Ferrari D, Bjorklund L, Dagher A, Isacson $O$ (2005) Cell type analysis of functional fetal dopamine cell suspension transplants in the striatum and substantia nigra of patients with Parkinson's disease. Brain 128:1498-1510.

Mendez I, Vinuela A, Astradsson A, Mukhida K, Hallett P, Robertson H, Tierney T, Holness R, Dagher A, Trojanowski JQ, Isacson O (2008) Dopamine neurons implanted into 
people with Parkinson's disease survive without pathology for 14 years. Nat Med 14:507-509.

Meredith JE, Jr., Fazeli B, Schwartz MA (1993) The extracellular matrix as a cell survival factor. Mol Biol Cell 4:953-961.

Michibata H, Okuno T, Konishi N, Kyono K, Wakimoto K, Aoki K, Kondo Y, Takata K, Kitamura Y, Taniguchi T (2009) Human GPM6A is associated with differentiation and neuronal migration of neurons derived from human embryonic stem cells. Stem Cells Dev 18:629-639.

Moos M, Tacke R, Scherer H, Teplow D, Fruh K, Schachner M (1988) Neural adhesion molecule L1 as a member of the immunoglobulin superfamily with binding domains similar to fibronectin. Nature 334:701-703.

Nakatomi H, Kuriu T, Okabe S, Yamamoto S, Hatano O, Kawahara N, Tamura A, Kirino T, Nakafuku M (2002) Regeneration of hippocampal pyramidal neurons after ischemic brain injury by recruitment of endogenous neural progenitors. Cell 110:429-441.

Nielsen J, Gotfryd K, Li S, Kulahin N, Soroka V, Rasmussen KK, Bock E, Berezin V (2009) Role of glial cell line-derived neurotrophic factor (GDNF)-neural cell adhesion molecule (NCAM) interactions in induction of neurite outgrowth and identification of a binding site for NCAM in the heel region of GDNF. J Neurosci 29:11360-11376.

Nikonenko A, Schmidt S, Skibo G, Bruckner G, Schachner M (2003) Tenascin-R-deficient mice show structural alterations of symmetric perisomatic synapses in the CA1 region of the hippocampus. J Comp Neurol 456:338-349.

Norenberg U, Hubert M, Brummendorf T, Tarnok A, Rathjen FG (1995) Characterization of functional domains of the tenascin- $\mathrm{R}$ (restrictin) polypeptide: cell attachment site, binding with F11, and enhancement of F11-mediated neurite outgrowth by tenascin-R. J Cell Biol 130:473-484.

Okabe S, Forsberg-Nilsson K, Spiro AC, Segal M, McKay RD (1996) Development of neuronal precursor cells and functional postmitotic neurons from embryonic stem cells in vitro. Mech Dev 59:89-102.

Ourednik J, Ourednik V, Lynch WP, Schachner M, Snyder EY (2002) Neural stem cells display an inherent mechanism for rescuing dysfunctional neurons. Nat Biotechnol 20:1103-1110.

Ourednik V, Ourednik J, Xu Y, Zhang Y, Lynch WP, Snyder EY, Schachner M (2009) Crosstalk between stem cells and the dysfunctional brain is facilitated by manipulating the niche: evidence from an adhesion molecule. Stem Cells 27:2846-2856.

Oyamada N, Itoh H, Sone M, Yamahara K, Miyashita K, Park K, Taura D, Inuzuka M, Sonoyama T, Tsujimoto H, Fukunaga Y, Tamura N, Nakao K (2008) Transplantation of vascular cells derived from human embryonic stem cells contributes to vascular regeneration after stroke in mice. J Transl Med 6:54.

Parent JM, Vexler ZS, Gong C, Derugin N, Ferriero DM (2002) Rat forebrain neurogenesis and striatal neuron replacement after focal stroke. Ann Neurol 52:802-813.

Pencea V, Bingaman KD, Wiegand SJ, Luskin MB (2001) Infusion of brain-derived neurotrophic factor into the lateral ventricle of the adult rat leads to new neurons in 
the parenchyma of the striatum, septum, thalamus, and hypothalamus. J Neurosci 21:6706-6717.

Pera MF, Andrade J, Houssami S, Reubinoff B, Trounson A, Stanley EG, Ward-van Oostwaard D, Mummery C (2004) Regulation of human embryonic stem cell differentiation by BMP-2 and its antagonist noggin. J Cell Sci 117:1269-1280.

Perrier AL, Tabar V, Barberi T, Rubio ME, Bruses J, Topf N, Harrison NL, Studer L (2004) Derivation of midbrain dopamine neurons from human embryonic stem cells. Proc Natl Acad Sci U S A 101:12543-12548.

Philpott LM, Kopyov OV, Lee AJ, Jacques S, Duma CM, Caine S, Yang M, Eagle KS (1997) Neuropsychological functioning following fetal striatal transplantation in Huntington's chorea: three case presentations. Cell Transplant 6:203-212.

Pruszak J, Sonntag KC, Aung MH, Sanchez-Pernaute R, Isacson O (2007) Markers and methods for cell sorting of human embryonic stem cell-derived neural cell populations. Stem Cells 25:2257-2268.

Pruszak J, Ludwig W, Blak A, Alavian K, Isacson O (2009) CD15, CD24, and CD29 define a surface biomarker code for neural lineage differentiation of stem cells. Stem Cells 27:2928-2940.

Raff MC (1992) Social controls on cell survival and cell death. Nature 356:397-400.

Rathjen FG, Schachner M (1984) Immunocytological and biochemical characterization of a new neuronal cell surface component (L1 antigen) which is involved in cell adhesion. EMBO J 3:1-10.

Rohwedel J, Maltsev V, Bober E, Arnold HH, Hescheler J, Wobus AM (1994) Muscle cell differentiation of embryonic stem cells reflects myogenesis in vivo: developmentally regulated expression of myogenic determination genes and functional expression of ionic currents. Dev Biol 164:87-101.

Roonprapunt C, Huang W, Grill R, Friedlander D, Grumet M, Chen S, Schachner M, Young W (2003) Soluble cell adhesion molecule L1-Fc promotes locomotor recovery in rats after spinal cord injury. J Neurotrauma 20:871-882.

Roy NS, Cleren C, Singh SK, Yang L, Beal MF, Goldman SA (2006) Functional engraftment of human ES cell-derived dopaminergic neurons enriched by coculture with telomerase-immortalized midbrain astrocytes. Nat Med 12:1259-1268.

Saghatelyan A, de Chevigny A, Schachner M, Lledo PM (2004) Tenascin-R mediates activitydependent recruitment of neuroblasts in the adult mouse forebrain. Nat Neurosci 7:347-356.

Sanchez-Pernaute R, Lee H, Patterson M, Reske-Nielsen C, Yoshizaki T, Sonntag KC, Studer L, Isacson O (2008) Parthenogenetic dopamine neurons from primate embryonic stem cells restore function in experimental Parkinson's disease. Brain 131:2127-2139.

Schachner M, Taylor J, Bartsch U, Pesheva P (1994) The perplexing multifunctionality of janusin, a tenascin-related molecule. Perspect Dev Neurobiol 2:33-41.

Schierle GS, Hansson O, Leist M, Nicotera P, Widner H, Brundin P (1999) Caspase inhibition reduces apoptosis and increases survival of nigral transplants. Nat Med 5:97-100.

Schmandt T, Meents E, Gossrau G, Gornik V, Okabe S, Brustle O (2005) High-purity lineage selection of embryonic stem cell-derived neurons. Stem Cells Dev 14:55-64. 
Schulz TC, Noggle SA, Palmarini GM, Weiler DA, Lyons IG, Pensa KA, Meedeniya AC, Davidson BP, Lambert NA, Condie BG (2004) Differentiation of human embryonic stem cells to dopaminergic neurons in serum-free suspension culture. Stem Cells 22:1218-1238.

Sharp J, Frame J, Siegenthaler M, Nistor G, Keirstead HS (2010) Human embryonic stem cellderived oligodendrocyte progenitor cell transplants improve recovery after cervical spinal cord injury. Stem Cells 28:152-163.

Shin MH, Lee EG, Lee SH, Lee YS, Son H (2002) Neural cell adhesion molecule (NCAM) promotes the differentiation of hippocampal precursor cells to a neuronal lineage, especially to a glutamatergic neural cell type. Exp Mol Med 34:401-410.

Silletti S, Mei F, Sheppard D, Montgomery AM (2000) Plasmin-sensitive dibasic sequences in the third fibronectin-like domain of L1-cell adhesion molecule (CAM) facilitate homomultimerization and concomitant integrin recruitment. J Cell Biol 149:14851502.

Sonntag KC, Pruszak J, Yoshizaki T, van Arensbergen J, Sanchez-Pernaute R, Isacson O (2007) Enhanced yield of neuroepithelial precursors and midbrain-like dopaminergic neurons from human embryonic stem cells using the bone morphogenic protein antagonist noggin. Stem Cells 25:411-418.

Tattersfield AS, Croon RJ, Liu YW, Kells AP, Faull RL, Connor B (2004) Neurogenesis in the striatum of the quinolinic acid lesion model of Huntington's disease. Neuroscience 127:319-332.

Teng YD, Lavik EB, Qu X, Park KI, Ourednik J, Zurakowski D, Langer R, Snyder EY (2002) Functional recovery following traumatic spinal cord injury mediated by a unique polymer scaffold seeded with neural stem cells. Proc Natl Acad Sci U S A 99:30243029.

Thomson JA, Itskovitz-Eldor J, Shapiro SS, Waknitz MA, Swiergiel JJ, Marshall VS, Jones JM (1998) Embryonic stem cell lines derived from human blastocysts. Science 282:11451147.

Tropepe V, Hitoshi S, Sirard C, Mak TW, Rossant J, van der Kooy D (2001) Direct neural fate specification from embryonic stem cells: a primitive mammalian neural stem cell stage acquired through a default mechanism. Neuron 30:65-78.

Wei L, Cui L, Snider BJ, Rivkin M, Yu SS, Lee CS, Adams LD, Gottlieb DI, Johnson EM, Jr., Yu SP, Choi DW (2005) Transplantation of embryonic stem cells overexpressing Bcl-2 promotes functional recovery after transient cerebral ischemia. Neurobiol Dis 19:183-193.

Wichterle H, Lieberam I, Porter JA, Jessell TM (2002) Directed differentiation of embryonic stem cells into motor neurons. Cell 110:385-397.

Wobus AM, Kaomei G, Shan J, Wellner MC, Rohwedel J, Ji G, Fleischmann B, Katus HA, Hescheler J, Franz WM (1997) Retinoic acid accelerates embryonic stem cell-derived cardiac differentiation and enhances development of ventricular cardiomyocytes. J Mol Cell Cardiol 29:1525-1539.

Yang D, Zhang ZJ, Oldenburg M, Ayala M, Zhang SC (2008) Human embryonic stem cellderived dopaminergic neurons reverse functional deficit in parkinsonian rats. Stem Cells 26:55-63. 
Yasuhara T, Matsukawa N, Hara K, Yu G, Xu L, Maki M, Kim SU, Borlongan CV (2006) Transplantation of human neural stem cells exerts neuroprotection in a rat model of Parkinson's disease. J Neurosci 26:12497-12511.

Yurek DM, Fletcher-Turner A (2004) Comparison of embryonic stem cell-derived dopamine neuron grafts and fetal ventral mesencephalic tissue grafts: morphology and function. Cell Transplant 13:295-306.

Zhang Y, Roslan R, Lang D, Schachner M, Lieberman AR, Anderson PN (2000) Expression of CHL1 and L1 by neurons and glia following sciatic nerve and dorsal root injury. Mol Cell Neurosci 16:71-86.

Zigova T, Pencea V, Wiegand SJ, Luskin MB (1998) Intraventricular administration of BDNF increases the number of newly generated neurons in the adult olfactory bulb. Mol Cell Neurosci 11:234-245.

Zuccato C, Cattaneo E (2009) Brain-derived neurotrophic factor in neurodegenerative diseases. Nat Rev Neurol 5:311-322. 


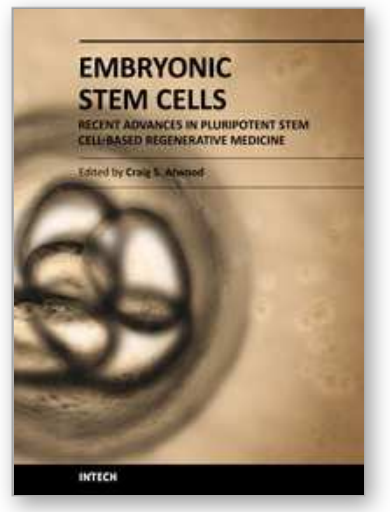

\section{Embryonic Stem Cells - Recent Advances in Pluripotent Stem Cell- Based Regenerative Medicine}

Edited by Prof. Craig Atwood

ISBN 978-953-307-198-5

Hard cover, 410 pages

Publisher InTech

Published online 26, April, 2011

Published in print edition April, 2011

Pluripotent stem cells have the potential to revolutionise medicine, providing treatment options for a wide range of diseases and conditions that currently lack therapies or cures. This book describes recent advances in the generation of tissue specific cell types for regenerative applications, as well as the obstacles that need to be overcome in order to recognize the potential of these cells.

\section{How to reference}

In order to correctly reference this scholarly work, feel free to copy and paste the following:

Gunnar Hargus and Christian Bernreuther (2011). Embryonic Stem Cells Overexpressing the Recognition Molecules L1 and Tenascin-R Enhance Regeneration in Mouse Models of Acute and Chronic Neurological Disorders, Embryonic Stem Cells - Recent Advances in Pluripotent Stem Cell-Based Regenerative Medicine, Prof. Craig Atwood (Ed.), ISBN: 978-953-307-198-5, InTech, Available from:

http://www.intechopen.com/books/embryonic-stem-cells-recent-advances-in-pluripotent-stem-cell-basedregenerative-medicine/embryonic-stem-cells-overexpressing-the-recognition-molecules-11-and-tenascin-renhance-regeneration

\section{INTECH}

open science | open minds

\section{InTech Europe}

University Campus STeP Ri Slavka Krautzeka 83/A 51000 Rijeka, Croatia Phone: +385 (51) 770447 Fax: +385 (51) 686166 www.intechopen.com

\section{InTech China}

Unit 405, Office Block, Hotel Equatorial Shanghai No.65, Yan An Road (West), Shanghai, 200040, China 中国上海市延安西路65号上海国际贵都大饭店办公楼 405 单元 Phone: +86-21-62489820

Fax: +86-21-62489821 
(C) 2011 The Author(s). Licensee IntechOpen. This chapter is distributed under the terms of the Creative Commons Attribution-NonCommercialShareAlike-3.0 License, which permits use, distribution and reproduction for non-commercial purposes, provided the original is properly cited and derivative works building on this content are distributed under the same license. 